\title{
Registration of Urjii, Field Pea Variety for Bale Highlands, Ethiopia
}

\section{Tadele Tadesse* and Edosa Fikru}

Sinana Agricultural Research Center, P O Box 208, Bale-Robe, Ethiopia

\begin{abstract}
Urjii (Acc. 32615-1) a semi-erect white seeded field pea variety has been selected and developed by Sinana Agricultural Research Center. The variety was released in 2007 for Bale highlands and similar agroecologies. This variety was tested in a regional variety trial in 12 environments, at four locations (Sinana, Sinja, Selka and Agarfa) in the highlands of Bale for three consecutive years (2003/04 to 2005/06). Due to its superior performance Uriji was selected and verified at four locations during bona 2006/07 cropping season and, there after, released for production. This variety is characterized by a white seed coat, with a high yield and yield advantage of $6.62 \%$ and $23.2 \%$ over the standard and local checks respectively. It is stable, adapts well, has a large number of pods per plant, thousand seed weight, and is moderately tolerant to powdery mildew, downey mildew and ascochyta blight.
\end{abstract}

Keywords: Uriii; Variety Registration

\section{Introduction}

Uriii (Acc. 32615-1) is a field pea variety developed and released in 2007 by Sinana Agricultural Research Center. It was originally obtained from locally collected germplasm. It was tested at Sinana on-station in a preliminary and advanced observation nursery and regional preliminary yield before the regional variety trial was conducted. After the regional variety trial had been conducted for three consecutive years (2003/04 to 2005/06), Urïi was verified over locations and evaluated by the National Variety Releasing Committee as per the guideline of the variety releasing and registration of the country during the 2007 cropping season.

\section{Evaluation}

One hundred test lines were tested for the first time in a preliminary observation nursery in the 2000/01 cropping season at Sinana on-station. Out of these, 49 of them were retained for further evaluation and tested in 2001 as advanced observation nursery and promising test lines from an advanced observation nursery and were promoted to be evaluated in a yield trial in 2002. Finally, twenty test lines were promoted to a regional variety trial. In the regional variety trial, Uriii (Acc. 32615-1) was evaluated in 12 environments (4 locations x 3 years) along with Weyitu (standard check) and local check both at Sinana on-station and on-farmers field (nine sites) in the highlands of Bale from 2003/04 to 2005/06 in major field pea production areas having an altitude of 1800-2600 m.a.sl and with an annual rainfall of $750 \mathrm{~mm}$ to $1000 \mathrm{~mm}$.

\section{Varietal Characters}

Uriii is a semi-erect white seeded field pea variety. On average, this variety needs 70 days for flowering, and 127 days to reach physiological maturity. It has a plant height of $119 \mathrm{~cm}$. It has a white seed coat with yellow cotyledon and a white flower. The average weight of a thousand seeds is $178.49 \mathrm{~g}$. On average, it produces 13 pods with medium length (Table 1).

\section{Yield Performance}

The average seed yield of Urjii combined over locations and over years is $4.16 \mathrm{t} / \mathrm{ha}$, which is higher than Weyitu (standard check $3.9 \mathrm{t} / \mathrm{ha}$ ), and the local check (3.3 t/ha). The variety provides a seed yield of $4.9 \mathrm{t} / \mathrm{ha}$ to $5.5 \mathrm{t} / \mathrm{ha}$ on the research field and $3.5 \mathrm{t} / \mathrm{ha}$ to $3.7 \mathrm{t} / \mathrm{ha}$ on the farmers' field. This variety has a yield advantage of $6.62 \%$ and $23.20 \%$ over the standard and local checks, respectively.

\section{Reaction to Disease}

The major field pea diseases according to their importance in the growing areas are powdery mildew (Erysiphe polygoni), downey mildew (Peronospora pisi) and Aschochyta blight (Mycosphaerella pinnodes) (Asfaw et al., 1993). On a 1-9 rating scale, Urjii scored a mean of 3 for all the above mentioned diseases. The variety is characterized by moderately resistance types of reaction to these major diseases at all the sites. The disease score for the variety and the checks are summarized in Table 1.

Table 1. Mean grain yield, other agronomic traits and disease reaction of Urïi and the checks in multi-location testing, 2003/4-2005/06.

\begin{tabular}{|c|c|c|c|c|c|c|c|c|c|c|c|}
\hline Entry & $\begin{array}{l}\text { Days } \\
\text { to } \\
\text { flower }\end{array}$ & $\begin{array}{l}\text { Days to } \\
\text { maturity }\end{array}$ & $\begin{array}{l}\text { Plant } \\
\text { height } \\
(\mathrm{cm})\end{array}$ & $\begin{array}{l}\text { No Pods } \\
\text { /plant }\end{array}$ & $\begin{array}{l}1000 \\
\text { Seed } \\
\text { wt }(g)\end{array}$ & \multicolumn{3}{|c|}{$\begin{array}{l}\text { Disease score }(1-9)^{\mathrm{a}} \\
\text { PM. DM. } \\
\text { ASCBLT }\end{array}$} & \multicolumn{3}{|c|}{$\begin{array}{l}\text { Mean grain yield } \\
(\mathrm{t} / \mathrm{ha})\end{array}$} \\
\hline $\begin{array}{l}\text { Urjii (Acc. } \\
32615-1\end{array}$ & 70 & 127 & 119 & 13 & 178.42 & 3 & 3 & 3 & $\begin{array}{l}\text { On-station b } \\
5.50\end{array}$ & $\begin{array}{l}\text { On-farm }{ }^{c} \\
3.71\end{array}$ & $\begin{array}{l}\text { Meand } \\
4.16\end{array}$ \\
\hline Weyitu & 68 & 128 & 125 & 9 & 183.10 & 6 & 6 & 6 & 5.04 & 3.52 & 3.90 \\
\hline Local check & 68 & 127 & 128 & 11 & 126.57 & 7 & 7 & 7 & 4.76 & 2.92 & 3.38 \\
\hline
\end{tabular}

Note PM = Powdery Mildew; DM =Downey Mildew; ASBLT = Ascochyta blight

${ }^{a}$ Disease score based on 1-9 scale where 1 is highly resisitance and 9 is bighly susceptible

${ }^{b}$ Average grain yield of research field for 3 environment (1 location $\times 3$ years)

$c$ Average grain yield of on farm for 9 environment ( 3 locations $\times 3$ yeas) 


\section{Quality}

The variety is preferred to a greater extent for kik rather than shiro. It is preferred both by consumers and producers due to its white seed color.

\section{Adaptation}

Uriii is released for the highlands of Bale. It performs very well in areas with an altitude of 1800 to 2600 m.a.s.l and an annual rain fall of 750 to $1000 \mathrm{~mm}$. It could also be possible to extend the production of this variety to other areas with similar agro-ecologies. This variety gives a better grain yield if produced with a recommended fertilizer rate of $100 \mathrm{~kg} \mathrm{DAP} / \mathrm{ha}$ and with a seed rate of $75 \mathrm{~kg} / \mathrm{ha}$ in clay-loam soil. For better performance of the variety, planting should be done from the end of July to early August in Meher and at the end of March during the Belg season.

\section{Variety Maintenance}

The Breeder and foundation seed of the variety is maintained by Sinana Agricultural research Center.

\section{Acknowledgement}

We thank OARI for financing the development of the variety. We also thank Sinana Agricultural Research Center Administration staff for facilitating the necessary requirements during the trials. We acknowledge Mr. Tamiru Tadesse, Mr. Siyum Ayele, Mr. G/Igziabher Reda, Mr. Hailu Tolosa, Mr. Hailu Reta and Mr. Negash Mohamed and staff of Breeding and Genetics at Sinana for data collection and trial management.

\section{Reference}

Asfaw, T., Beyene, D. and Tesfaye, G. 1993. Genetics and breeding of Field pea. In: Cool-season Food Legumes of Ethiopia. Proceeding of the first National Cool-season Food Legumes Review conference, 16-20 December 1993. Addis Ababa, Ethiopa. pp. 122-137. 